\title{
EFEKTIVITAS AKTIVITAS MENGHITUNG BERKAT (COUNTING BLESSING) TERHADAP KEPUASAN PERKAWINAN
}

\author{
Imelda Ika Dian Oriza ${ }^{1}$, Hasna Nadira ${ }^{2}$, Mutia Ardi $^{3}$ dan Nadira Khairunnisa ${ }^{4}$ \\ ${ }^{1}$ Fakultas Psikologi, Universitas Indonesia, Depok \\ Email: dian.oriza@gmail.com \\ ${ }^{2}$ Fakultas Psikologi, Universitas Indonesia, Depok \\ Email: hasnanadira@gmail.com \\ ${ }^{3}$ Fakultas Psikologi, Universitas Indonesia, Depok \\ Email: mutiaardi95@gmail.com \\ ${ }^{4}$ Fakultas Psikologi, Universitas Indonesia, Depok \\ Email: nadira1803@gmail.com
}

\begin{abstract}
Marriage satisfaction is an important factor that is not only related to relationship in marriage, but also to individual well-being. In the realm of positive psychology, positive activity is an activity that is known to have a positive impact on improving the quality of individual relationships. Through this study, researchers aim to test the effectiveness of the activity of counting blessings on marital satisfaction. The study was conducted using experimental method involving 58 participants randomly divided into two groups, namely the group that performs the counting blessings activity $(n=21)$ and the group that does not perform counting blessings activity $(n=37)$. The participants of the experimental group were asked to record the things they were grateful for about their spouses for 14 consecutive days. While the control group was only asked to fill out marriage satisfaction questionnaire before and after the test. The level of marital satisfaction was measured using the measurement of the Enrich Marital Satisfaction Scale (EMS). The selection of participants by convenience sampling technique was carried out to acquire married participants with the marriage age range of 1 to 13 years, living together with their respective spouse, and having completed at least diploma education. The result of this study shows that there is no significant difference in the level of marital satisfaction of participants before and after performing the counting blessings activity with (20) $=-0.39, p>0.05$. In addition, the result of this study also sees that there is no significant difference between the group that performs the counting blessings activity and the group that does not perform the activity on marital satisfaction level $U=34.10, z=-0.77, n s(p>0.05)$
\end{abstract}

Keywords: positive activity; counting blessings activity; marital satisfaction

\begin{abstract}
ABSTRAK
Kepuasan perkawinan menjadi faktor penting yang tidak hanya terkait dengan relasi dalam perkawinan, tetapi juga pada kesejahteraan individu. Dalam ranah psikologi positif, aktivitas positif merupakan salah satu kegiatan yang diketahui berdampak positif dalam meningkatkan kualitas relasi individu. Melalui penelitian ini, peneliti bertujuan menguji efektivitas aktivitas menghitung berkat terhadap kepuasan perkawinan. Penelitian dilakukan menggunakan metode eksperimental dengan melibatkan 58 partisipan yang terbagi menjadi dua kelompok secara acak, yaitu kelompok yang melakukan aktivitas menghitung berkat $(n=21)$ dan kelompok yang tidak melakukan aktivitas menghitung berkat $(n=37)$. Partisipan kelompok eksperimen diminta untuk mencatat hal-hal yang disyukuri dari atau terhadap pasangan selama 14 hari berturut-turut. Sementara kelompok kontrol hanya diminta untuk mengisi kuesioner kepuasan perkawinan sebelum dan setelah test. Tingkat kepuasan perkawinan diukur menggunakan alat ukur Enrich Marital Satisfaction Scale (EMS). Pemilihan partisipan dengan teknik convenience sampling dilakukan untuk menjaring partisipan yang sudah menikah dan berada dalam rentang usia perkawinan antara 1 sampai 13 tahun, tinggal satu rumah dengan pasangan, dan berpendidikan terakhir minimal diploma. Hasil penelitian ini menunjukkan tidak terdapat perbedaan signifikan pada tingkat kepuasan perkawinan partisipan sebelum dan setelah melakukan aktivitas menghitung berkat $t(20)=-0,39, p>0,05$. Selain itu hasil penelitian ini juga melihat bahwa tidak ada perbedaan signifikan antara kelompok yang melakukan aktivitas menghitung berkat dan kelompok yang tidak melakukan aktivitas tersebut terhadap tingkat kepuasan perkawinan $U=34,10, z=-0,77, n s(p>0,05)$. Kata kunci: aktivitas positif; aktivitas menghitung berkat; kepuasan perkawinan
\end{abstract}




\section{PENDAHULUAN}

\section{Latar Belakang}

Pada tahap usia dewasa, perkawinan menjadi relasi yang berperan penting pada diri individu. Hal ini terkait dengan tugas perkembangan yang menuntut individu dalam tahap usia dewasa untuk menjalin hubungan yang intim dan berkomitmen dengan orang lain, yaitu untuk hidup bersama, membangun keluarga, dan memiliki anak yang dicapai melalui perkawinan (Papalia, Olds, \& Feldman, 2009). Sebagian besar orang menganggap bahwa perkawinan merupakan sumber dari kepuasan dan pemenuhan kebutuhan dalam hidup (Karney \& Bradburry, 1995).

Menurut Olson dan DeFrain (2006), perkawinan yang sukses dapat menjadi aset berharga dalam kehidupan seseorang, seperti menjadi faktor yang melindungi individu dari berbagai stres (Fincham, Beach, \& Davila, 2007) dan memberikan kesehatan mental yang lebih baik (Beach, Katz, Kim, \& Brody dalam Malouff, Thorsteinsson, Schutte, Bhullar, \& Rooke, 2010). Akan tetapi, apabila kualitas perkawinan yang dijalani individu cenderung rendah, maka hal ini dapat berdampak pada penurunan kesehatan psikologis, meningkatkan stres psikologis (Ross, Mirowsky, \& Goldsteen, 1990) serta meningkatkan resiko penyakit (DeGenova, 2008).

Relasi perkawinan yang tidak berjalan dengan baik juga dapat berakhir dengan perceraian. Berdasarkan data yang dihimpun oleh Badan Pusat Statistik (2015), angka perceraian di Indonesia pada tahun 2015 tercatat sebanyak 347.256, yang mana jumlah ini meningkat 3\% dibandingkan tahun sebelumnya. Menurut Sari dan Sukmawati (2015), beberapa faktor yang seringkali menjadi penyebab perceraian antara lain, sikap egosentrisme, perilaku marah, perselingkuhan, faktor ekonomi, dan tekanan stres. Faktor-faktor tersebut menunjukkan bahwa kesejahteraan mental berperan penting dalam membangun relasi perkawinan yang berkualitas.

Kualitas hubungan perkawinan dapat dilihat berdasarkan kebahagiaan, cinta, afeksi, komunikasi, kedekatan, komitmen, dan kepuasan dalam perkawinan (Ahangar, Juhari, Yaacob, \& Talib, 2016). Pada penelitian di bidang perkawinan, kepuasan perkawinan menjadi variabel yang banyak diteliti karena kepuasan perkawinan menjadi salah satu penentu dalam perkawinan yang bahagia dan berkualitas.

Secara umum kepuasan perkawinan merupakan perasaan subjektif atas kebahagiaan, kepuasan, dan kesenangan yang dirasakan seseorang terhadap perkawinannya (Olson dan De Frain, 2006). Kepuasan perkawinan juga bisa dilihat sebagai mental state yang merefleksikan manfaat dan kerugian yang dipersepsi individu terhadap hubungan perkawinannya (Atta, Adnan, Sultan, \& Sabira, 2013). Sejalan dengan definisi tersebut, Spainer dan Cole (dalam Prasetya, 2007), melihat kepuasan perkawinan sebagai evaluasi subjektif mengenai perasaan individu terhadap pasangannya. Evaluasi tersebut meliputi dukungan dan pengertian secara emosional, kemandirian, penyelesaian masalah dan resolusi konflik dalam hubungan perkawinan. Apabila aspek tersebut memiliki kualitas yang kurang baik, maka dapat berdampak pada timbulnya berbagai masalah dalam perkawinan, seperti terhambatnya komunikasi, kecemasan, perselingkuhan, ketidakpuasan seksual, dan depresi (Greeff \& Bruyne, 2000). Sementara apabila seseorang mempersepsi aspek tersebut secara positif, maka semakin puas pula hubungan yang terjalin dengan pasangan maupun perkawinannya (Stone \& Shackelford, 2006).

Beberapa faktor yang dapat memengaruhi kepuasan perkawinan antara lain latar belakang dari masing-masing pasangan maupun kondisi pasangan setelah menikah. Menurut Duvall dan Miller (1985), latar belakang seseorang dibesarkan di keluarganya memiliki pengaruh terhadap hubungan perkawinannya kelak. Latar belakang tersebut dapat meliputi kebahagiaan masa kecil, disiplin, pendidikan seks, dan pendidikan formal. Sementara kondisi pasangan setelah menikah 
terkait dengan afeksi atau ekspresi individu dalam menunjukkan kasih sayang terhadap orang lain, kepercayaan diri atau kepercayaan satu sama lain, kesetaraan, komunikasi, hubungan intim yang saling memuaskan, kehidupan sosial, tempat tinggal yang tetap untuk keberlangsungan hidup, serta pendapatan yang mencukupi untuk masing-masing pasangan (Duvall \& Miller, 1985). Terkait dengan kondisi finansial, Stone dan Shackelford (2007) menambahkan bahwa masalah ekonomi dan pekerjaan seringkali menyebabkan penurunan kepuasan perkawinan. Hal ini karena masalah keuangan dianggap rentan menjadi sumber stress, ketegangan dan ketidakpuasan individu dalam hidup bersama (Mohsin, 2014). Selain itu, kepribadian pasangan, perilaku protektif, kemungkinan pasangan berselingkuh, value atau keberhargaan pasangan, dan keberadaan anak juga dianggap turut berperan dalam memengaruhi kepuasan perkawinan seseorang (Karney \& Bradburry, 1995).

Faktor lain yang memengaruhi kepuasan perkawinan yaitu terkait dengan usia perkawinan. Menurut Stone dan Shackelford (2007), kepuasan perkawinan berkembang mengikuti bentuk U. Artinya, pasangan cenderung puas pada awal perkawinan, namun seiring meningkatnya usia perkawinan secara perlahan kepuasan akan menurun dan kemudian akan kembali meningkat seperti pada awal perkawinan. Williams, Sawyer, dan Wahlstrom (2006) mengemukakan adanya empat fase family life cycle. (1) Fase pertama berlangsung hingga dua sampai tiga tahun awal sebelum anak pertama lahir. Pada fase ini, sebagian besar pasangan melaporkan kepuasan perkawinan yang paling tinggi. (2) Fase kedua merupakan fase dimana pasangan fokus membesarkan anak. Pada fase ini, kepuasan perkawinan mulai menurun. (3) Fase ketiga atau disebut middle-age phase, dimulai saat anak terakhir meninggalkan rumah hingga pensiun. Pada fase ini, beberapa orangtua mengalami empty-nest syndrome, yaitu depresi setelah anak tidak lagi tinggal bersama orangtua.

Berdasarkan Karney dan Bradburry (1995), terdapat lima komponen dalam kepuasan perkawinan yang antara lain: (a) kognisi, untuk melihat apakah tindakan dari pasangan dapat merugikan atau menguntungkan bagi diri (b) fisiologis, dimana dalam beberapa penelitian menunjukkan bahwa pasangan yang puas dengan perkawinannya juga merasakan kebugaran fisik (c) pola interaksi antar pasangan, dimana ketika salah satu dari pasangan sering mengeluh atau mengkritik perubahan, sementara pasangannya cenderung menghindari perbincangan tersebut maka hal ini dapat memunculkan jarak dalam hubungan dan memengaruhi kepuasan perkawinan (d) dukungan pasangan, dimana pemberian dukungan memiliki asosiasi terhadap kepuasan perkawinan yang baik serta mewujudkan keluarga yang sehat (e) kekerasan, dimana individu yang sering terlibat hubungan dengan kekerasan cenderung tidak puas terhadap hubungan perkawinannya. Meski kepuasan perkawinan bersifat fluktuatif, setiap pasangan yang menikah tentu menginginkan perkawinan yang berkualitas, bertahan lama, dan dapat memberikan kebahagiaan.

Dalam ranah psikologi positif, upaya untuk memperkuat relasi individu dapat dilakukan melalui aktivitas positif. Berdasarkan definisinya, aktivitas positif merupakan aktivitas yang dilakukan untuk menanamkan perasaan, perilaku, dan kognisi yang positif (Sin \& Lyubomirsky, 2009). Intervensi ini diberikan dalam bentuk kegiatan sederhana yang dilakukan secara teratur dan sengaja, yang bertujuan untuk membentuk perilaku tertentu dan pengalaman sehat (Lyubomirsky \& Layous, 2013). Kegiatan yang dilakukan dalam aktivitas positif diyakini berkontribusi pada emosi positif seseorang dan menjadi strategi penting untuk dapat meningkatkan kesejahteraan mental (Bolier, Haverman, Westerhof, Riper, Smit, \& Bohlmeijer, 2013). Hal ini sejalan dengan penelitian sebelumnya yang menemukan bahwa melakukan tindakan baik kepada orang lain membuat individu merasa lebih bahagia, sejahtera, dan puas terhadap hidupnya (Kerr, 
O’Donnovan, \& Pepping, 2015; Buchanan \& Bardi, 2010; Lyubomirsky, Sheldon \& Schkade, 2005).

Beberapa penelitian sebelumnya telah mengembangkan berbagai aktivitas positif, yaitu aktivitas mengekspresikan rasa syukur (expressing gratitude) (Seligman, Steen, Park, \& Peterson, 2005), membayangkan diri dalam versi terbaik (visualize ideal future selves) (Sheldon \& Lyubomirsky, 2006), dan menghitung kebaikan (counting kindness) (Otake, Shimai, Tanaka-Matsumi, Otsui, \& Fredrickson, 2006). Beragam aktivitas positif tersebut dikembangkan setelah Emmons dan McCullough (2003) melakukan penelitian aktivitas positif berupa aktivitas menghitung berkat (counting blessing) untuk meningkatkan rasa syukur dan subjective well being individu dalam kehidupan sehari-hari.

Penelitian Emmons dan McCullough (2003) dilakukan dengan meminta partisipan untuk membuat daftar hal-hal yang disyukuri setiap harinya dan dicatat dalam jurnal harian. Hasil penelitian ini menunjukkan bahwa aktivitas menghitung berkat dapat meningkatkan kebahagiaan dan kesejahteraan seseorang. Setelah penelitian yang dilakukan oleh Emmons dan McCullough (2003), penelitian lain terkait aktivitas menghitung berkat mulai dilakukan di berbagai latar.

Beberapa penelitian aktivitas menghitung berkat yang telah dilakukan sebelumnya menemukan bahwa hal-hal yang dianggap sebagai berkat tidak hanya terkait dengan diri individu, tetapi partisipan juga memaknai relasi dengan orang-orang di sekitarnya sebagai suatu berkat. Hal ini terlihat dari penelitian yang dilakukan oleh Gordon, Musher-Eizenman, Holub, dan Dalrymple (2004), dimana sebagian besar partisipan mencatat dalam jurnal harian mereka mengenai keluarga, teman, dan guru di sekolah sebagai hal-hal yang disyukuri. Penemuan serupa juga terlihat dalam penelitian Froh, Sefick, dan Emmons (2008). Pada penelitian tersebut banyak partisipan yang menuliskan terkait keluarga, teman, dan guru di sekolah sebagai suatu berkat yang disyukuri oleh partisipan. Berdasarkan penemuan dari penelitian-penelitian tersebut dapat terlihat bahwa relasi interpersonal menjadi aspek yang dimaknai sebagai suatu berkat oleh individu. Selain dimaknai sebagai suatu berkat, aktivitas positif juga dianggap mampu memperkuat relasi. Menurut Layous, Chancellor, dan Lyubomirsky (2014), aktivitas positif yang dilakukan oleh partisipan dapat meningkatkan emosi positif selama intervensi. Emosi positif yang timbul pada diri individu mengarahkan pada meningkatnya persepsi akan dukungan sosial dan relasi dengan orang lain sehingga menghasilkan relasi yang positif. Meski demikian, saat ini belum ada penelitian empiris mengenai implikasi aktivitas positif berupa aktivitas menghitung berkat terhadap relasi dalam perkawinan, khususnya terkait dengan kepuasan perkawinan. Oleh karena itu, penelitian ini bertujuan untuk melihat efektivitas dari aktivitas menghitung berkat terhadap kepuasan perkawinan.

Hipotesis penelitian ini yaitu (1) terdapat perbedaan rata-rata skor kepuasan perkawinan yang signifikan sebelum dan setelah melakukan aktivitas menghitung berkat, dan (2) terdapat perbedaan rata-rata skor yang signifikan pada kelompok yang melakukan aktivitas menghitung berkat dan yang tidak melakukan aktivitas tersebut.

\section{METODE PENELITIAN}

Penelitian ini merupakan penelitian eksperimental dengan desain kelompok kontrol pre-test dan post-test yang dirandomisasi (randomized pretest-posttest control group). Partisipan yang terlibat dalam penelitian ini memiliki kriteria antara lain, (1) sudah menikah dengan usia perkawinan 1 hingga 13 tahun, (2) tinggal satu rumah dengan pasangan, dan (3) memiliki tingkat pendidikan minimal D3. Proses pemilihan partisipan dilakukan melalui teknik covenience 
sampling. Perekrutan partisipan dilakukan dengan menyebarkan informasi melalui poster dan pesan singkat di sosial media. Lima partisipan beruntung yang mengikuti rangkaian penelitian secara lengkap akan diundi untuk mendapat hadiah berupa kupon belanja senilai Rp. 500.000,00 untuk tiap partisipan.

Partisipan yang memiliki kesesuaian karakteristik dan bersedia mengikuti penelitian diminta untuk mengisi kuesioner secara online untuk mengukur tingkat kepuasan perkawinan (pre-test). Penelitian ini mengadaptasi studi yang telah dilakukan Emmons dan Mccullough (2003), yaitu dengan meminta partisipan melakukan aktivitas menghitung berkat. Partisipan diminta untuk memikirkan dan menuliskan sebanyak lima hal yang mereka syukuri terkait dengan pasangan atau perkawinannya yang terjadi pada hari itu. Aktivitas ini berlangsung selama dua minggu. Partisipan diminta menuliskan setiap hari di malam hari mulai pukul 19.00 WIB hingga sebelum tidur. Dua minggu setelah hari terakhir pengisian aktivitas menghitung berkat, peneliti kembali meminta partisipan mengisi kuesioner untuk mengukur kepuasan perkawinan (post-test).

Kepuasan perkawinan diukur menggunakan Enrich Marital Satisfaction Scale (EMS) yang telah diadaptasi oleh Juwita (2013). Alat ukur EMS pada awalnya dikembangkan oleh Fowers dan Olson pada tahun 1993 dengan reliabilitas yang baik, yaitu dengan Cronbach's alpha 0,86 dan validitas yang telah diuji di berbagai penelitian. Alat ukur ini kemudian diadaptasi oleh Juwita (2013). Setelah diadaptasi, alat ukur EMS memiliki reliabilitas yang juga baik dengan Cronbach's alpha sebesar 0,908.

EMS merupakan alat ukur multidimensional yang terdiri dari 16 item favorable. Keseluruhan item dinilai menggunakan skala Likert dengan rentang 1 (sangat tidak puas) hingga 6 (sangat puas). Partisipan diminta untuk menilai seberapa besar pernyataan yang tertera menggambarkan kondisi perkawinan partisipan saat ini. Dalam menilai tingkat kepuasan perkawinan partisipan, peneliti akan menjumlahkan skor dari tiap item sehingga akan memunculkan rentang skor yang berkisar antara 16 hingga 96. Dengan demikian, semakin tinggi total skor EMS yang diperoleh partisipan, maka semakin tinggi kepuasan partisipan terhadap perkawinan yang ia jalani (Fowers \& Olson, 1993).

Dalam melakukan teknik analisis, peneliti memisahkan data partisipan yang mengikuti keseluruhan rangkaian penelitian dan partisipan yang tidak mengikuti penelitian hingga selesai. Data partisipan yang mengikuti penelitian secara penuh akan diolah dengan melihat data pre-test dan post-test masing-masing partisipan. Pengujian hipotesis penelitian dilakukan dengan melihat perbedaan selisih skor kepuasan perkawinan sebelum dan setelah diberikan perlakuan (gain score) pada kelompok kontrol dan kelompok eksperimen untuk melihat pengaruh aktivitas menghitung berkat terhadap kepuasan perkawinan kedua kelompok tersebut. Selanjutnya, data yang diperoleh akan diolah secara kuantitatif menggunakan program SPSS dengan teknik Paired T-test. 


\section{HASIL DAN PEMBAHASAN}

Terdapat 58 partisipan terlibat dalam penelitian. Partisipan dibagi ke dalam Kelompok Eksperimen $(n=21)$ dan Kelompok Kontrol $(n=37)$. Berikut gambaran demografis partisipan dalam penelitian. Berdasarkan gambaran umum, partisipan penelitian terdiri dari 8 orang partisipan pria $(13,79 \%)$ dan 50 partisipan wanita $(86,20 \%)$ dengan rentang usia 22 hingga 40 tahun $(\mathrm{M}=28,94, \mathrm{SD}=4,56)$. Rata-rata usia perkawinan partisipan yaitu 3 tahun 9 bulan $(\mathrm{SD}=2,97)$ dengan rata-rata jumlah anak partisipan berjumlah 1 orang $(39,60 \%)$. Sementara berdasarkan tingkat pendidikan, partisipan memiliki tingkat pendidikan beragam antara lain, diploma $(5,17 \%)$, sarjana $(49,13 \%)$, dan pascasarjana $(27,58 \%)$.

Berdasarkan hasil uji normalitas dan homogenitas kepuasan perkawinan menggunakan Kolmogorov-Smirnov, diperoleh $D(21)=0,156, p>0,05$ untuk kelompok eksperimen. Hasil ini menunjukkan bahwa skor kepuasan perkawinan Kelompok Eksperimen terdistribusi normal sehingga peneliti menggunakan Paired T-test untuk uji statistik selanjutnya.

Uji normalitas dan homogenitas juga dilakukan pada kedua kelompok, yaitu Kelompok Kontrol dan Kelompok Eksperimen yang dilakukan menggunakan Kolmogorov-Smirnov. Pada Kelompok Kontrol diperoleh $T(37)=0,005, p<0,05$, sedangkan pada Kelompok Eksperimen menunjukkan hasil $T(21)=0,200, p>0,05$. Hasil tersebut menunjukkan bahwa pada Kelompok Kontrol, gain score kepuasan perkawinan tidak terdistribusi secara normal, akan tetapi pada Kelompok Eksperimen gain score kepuasan perkawinan terdistribusi normal. Peneliti juga melakukan uji homogenitas menggunakan Levene Test yang menunjukkan hasil $F(1,56)=0,553$, $\mathrm{p}=0,460$. Berdasarkan hasil tersebut terlihat bahwa tidak ada perbedaan varians yang signifikan antar kedua kelompok.

Hasil uji statistik menggunakan Paired T-test menunjukkan bahwa tingkat kepuasan perkawinan partisipan Kelompok Eksperimen sebelum melakukan aktivitas menghitung berkat $(M=77,52$, $S D=10,41)$ tidak berbeda secara signifikan dengan tingkat kepuasan perkawinan partisipan setelah melakukan aktivitas menghitung berkat $(M=78,19, S D=12,63), t(20)=-0,39, p>0,05$. Berdasarkan hasil tersebut dapat disimpulkan bahwa aktivitas menghitung berkat tidak berpengaruh signifikan terhadap tingkat kepuasan perkawinan partisipan Kelompok Eksperimen. Artinya, hipotesis 1 penelitian ditolak.

Sementara berdasarkan uji Mann-Whittney Test, tingkat kepuasan perkawinan kelompok eksperimen yang melakukan aktivitas menghitung berkat $(M=31,76)$ tidak berbeda secara signifikan dengan Kelompok Kontrol $(M=28,22) U=34,10, z=-0,77, n s \quad(p>0,05)$. Hasil ini menunjukkan bahwa hipotesis 2 ditolak. Dapat disimpulkan, tidak ada perbedaan signifikan pada tingkat kepuasan perkawinan antara kelompok yang melakukan aktivitas menghitung berkat dan kelompok yang tidak melakukan aktivitas tersebut.

Berdasarkan hasil penelitian ini dapat terlihat bahwa meski penelitian Emmons dan McCullough (2003) menyatakan aktivitas menghitung berkat dapat membangun dan memperkuat relasi, pada penelitian ini, aktivitas menghitung berkat tidak berpengaruh signifikan terhadap kepuasan perkawinan. Peneliti berasumsi, alasan kedua hipotesis penelitian ditolak karena adanya beberapa faktor yang antara lain, perlu adanya ekspresi dari penghayatan pribadi partisipan atas berkat yang dirasakan, durasi dilakukannya aktivitas positif, kehadiran anak, usia perkawinan, dan kesesuaian individu dengan aktivitas menghitung berkat. 
Pada penelitian ini, partisipan terlihat mampu menuliskan berkat yang dirasakan berdasarkan penghayatan pribadi. Meskipun demikian, berdasarkan penelitian yang dilakukan oleh O'Connell, O'Shea, dan Gallagher (2016), aktivitas positif dengan melakukan kebaikan dan menunjukkan rasa syukur kepada orang-orang disekitar perlu didukung dengan ungkapan atau ekspresi atas berkat yang dirasakan. Dalam penelitian tersebut terlihat bahwa partisipan yang hanya menuliskan hal-hal yang disyukuri tanpa menunjukkan rasa syukurnya kepada orang lain dianggap kurang efektif dalam meningkatkan kualitas hubungan, namun dengan mengungkapkan atau mengekspresikan, orang lain pun dapat merasakan berkat atau perasaan positif dari relasi yang terjalin. Hal inilah yang memengaruhi interaksi individu dan meningkatkan kualitas hubungan.

Kepuasan perkawinan dipengaruhi oleh beragam faktor yang memengaruhi penilaian subjektif individu terhadap hubungan perkawinan. Selain itu, kepuasan perkawinan pun bersifat fluktuatif dan dapat berubah dalam kurun waktu tahunan (Stone \& Shackleford, 2007). Dengan demikian, untuk dapat mengubah evaluasi individu terhadap hubungan perkawinan akan membutuhkan waktu yang cukup panjang dan intensif. Sementara dalam penelitian ini, partisipan hanya melakukan aktivitas menghitung berkat selama dua minggu sehingga pengaruh aktivitas menghitung berkat kurang dapat terlihat pengaruhnya pada kepuasan perkawinan partisipan.

Faktor lain yang juga memengaruhi kepuasan perkawinan terkait dengan kehadiran anak. Disatu sisi kehadiran anak dapat meningkatkan stabilitas perkawinan, namun di sisi lain dapat pula menurunkan kepuasan perkawinan (Stone \& Shackelford, 2007). Meskipun kehadiran anak dapat membawa perasaan senang bagi pasangan, tetapi dalam mengasuh dan membesarkan anak juga memerlukan usaha, waktu, dan tanggung jawab besar (Williams, Sawyer, \& Wahlstrom, 2006). Partisipan dalam penelitian ini rata-rata memiliki satu orang anak. Pada kondisi pasangan yang telah memiliki anak, partisipan akan menghabiskan waktu dan energi untuk mengurus anak. Kondisi ini membuat partisipan mengalami kesulitan untuk dapat meluangkan waktu secara optimal dalam menghitung berkat.

Usia perkawinan diketahui turut berperan dalam kepuasan perkawinan seseorang. Pada dasarnya, kepuasan perkawinan diyakini mengikuti lintasan berbentuk-U. Di awal perkawinan, pasangan memulai hubungan dengan rasa puas, kemudian kepuasan perkawinan akan menyusut selama beberapa tahun, dan setelahnya akan kembali mencapai kepuasan awal beberapa tahun berikutnya (Stone \& Shackelford, 2007). Partisipan yang terlibat dalam penelitian ini, rata-rata berada pada usia perkawinan tiga tahun sembilan bulan. Berdasarkan family life cycle yang dikemukakan oleh Williams, Sawyer, dan Wahlstrom (2006), rata-rata usia perkawinan partisipan berada pada fase pertama. Usia perkawinan dalam fase pertama berkisar antara dua hingga tiga tahun pertama perkawinan. Pada tahap ini, sebagian besar pasangan mengungkapkan tingkap kepuasan perkawinan yang tinggi. Oleh karena itu, dengan usia perkawinan partisipan yang berada pada fase pertama, kepuasan perkawinan partisipan pun cenderung relatif stabil.

Kesesuaian individu dalam melakukan aktivitas menghitung berkat (person-activity fit) juga memengaruhi efektivitas dari aktivitas tersebut. Dalam melakukan aktivitas positif, individu perlu memiliki ketertarikan dan kesesuaian dengan nilai yang ia percayai untuk memeroleh manfaat yang lebih optimal dari aktivitas positif yang dilakukan (Layous \& Lyubomirsky, 2012). Peneliti menduga, partisipan dalam penelitian ini memiliki perbedaan nilai dengan aktivitas positif yang dilakukan, sehingga partisipan kurang mendapat manfaat dari aktivitas menghitung berkat. Sementara, perasaan positif dapat terbentuk jika hal tersebut menyentuh afek seseorang, dan perasaan positif baru dapat menyentuh afek ketika seseorang benar-benar mendalami 
perasaan tersebut dan merefleksikannya secara berulang (Emmons \& McCullough, 2003). Apabila aktivitas positif yang dilakukan kurang sesuai dengan nilai yang diyakini, maka seseorang cenderung kurang mendalami penghayatan atas aktivitas yang dilakukan. Pada penelitian ini, partisipan cenderung menuliskan hal yang sangat umum dan hal tersebut dituliskan berulang setiap harinya. Kurangnya penghayatan pribadi partisipan terhadap aktivitas yang dilakukan membuat partisipan kurang memeroleh manfaat atas aktivitas menghitung berkat.

\section{KESIMPULAN DAN SARAN}

Berdasarkan hasil penelitian ini dapat disimpulkan bahwa aktivitas menghitung berkat tidak berpengaruh signifikan terhadap kepuasan perkawinan. Meskipun demikian, penelitian ini dapat menjadi acuan untuk penelitian selanjutnya. Mengingat bahwa penelitian sebelumnya menunjukkan adanya dampak positif aktivitas menghitung berkat terhadap relasi individu, penelitian ini masih dapat dikembangkan terutama dengan menyesuaikan pada budaya di Indonesia. Adapun saran untuk penelitian selanjutnya dapat mengacu pada keterbatasan dalam penelitian ini. Pertama, penelitian selanjutnya dapat menambahkan jumlah partisipan, terutama partisipan laki-laki untuk mengetahui perbedaan kepuasan perkawinan antara laki-laki dan perempuan. Kedua, menambahkan periode aktivitas menghitung berkat yang dimaksudkan untuk membentuk kebiasaan partisipan terhadap aktivitas yang dilakukan. Ketiga, mengingat bahwa perkembangan kepuasan perkawinan cenderung dalam jangka waktu lama, penelitian selanjutnya dapat dilakukan secara longitudinal.

Ucapan Terima Kasih (Acknowledgement)

Peneliti mengucapkan terima kasih kepada seluruh partisipan yang telah berpartisipasi serta pihak-pihak yang terlibat dalam penelitian ini.

\section{REFERENSI}

Ahangar, K., Juhari, R., Yaacob, S. N., \& Talib, M. A. (2016). Demographic factors and marital satisfaction among Iranian married students in malaysia. Asian Journal of Social Sciences \& Humanities, 5(2), 153-163.

Atta, M., Adnan, A., Sultan, S., \& Sabira, S. (2013). Role of trust in marital satisfaction among single and dual-career couples. International Journal of Research Studies in Psychology, 53-62.

Badan Pusat Statistik. (2015). Nikah, talak, dan cerai, serta rujuk 2012-2015. Diunduh dari https://www.bps.go.id/linkTableDinamis/view/id/893

Bolier, L., Haverman, M., Westerhof, G. J., Riper, H., Smit, F., \& Bohlmeijer, E. (2013). Positive psychology interventions: a meta-analysis of randomized controlled studies. BMC Public Health, 13(1), 119.

DeGenova, M. K. (2008). Intimate relationships, marriages, \& families. New York, NY: McGraw Hill.

Duvall, E. R. M., \& Miller, B. C. (1985). Marriage and family development. New York: Harper \& Row.

Emmons, R. A., \& McCullough, M. E. (2003). Counting Blessings Versus Burdens: An Experimental Investigation of Gratitude and Subjective Well-Being in Daily Life. Journal 
of Personality and Social Psychology, 84(2), 377-389. https://doi.org/10.1037//00223514.84.2.377

Fincham, F. D., Beach, S. R., \& Davila, J. (2007). Longitudinal relations between forgiveness and conflict resolution in marriage. Journal of Family Psychology, 21(3), 542.

Fowers, B. J., \& Olson, D. H. (1993). ENRICH Marital Satisfaction Scale: A brief research and clinical tool. Journal of Family psychology, 7(2), 176.

Froh, J. J., Sefick, W. J., \& Emmons, R. A. (2008). Counting blessings in early adolescents: An experimental study of gratitude and subjective well-being. Journal of School Psychology, 46(2), 213-233. https://doi.org/10.1016/j.jsp.2007.03.005

Gordon, A. K., Musher-Eizenman, D. R., Holub, S. C., \& Dalrymple, J. (2004). What are children thankful for? An archival analysis of gratitude before and after the attacks of September 11. Journal of Applied Developmental Psychology, 25(5), 541-553. https://doi.org/10.1016/j.appdev.2004.08.004

Juwita, R. (2013). Hubungan antara cinta dan kepuasan perkawinan pada individu dalam tahap awal perkawinan. Skripsi. Program Sarjana Universitas Indonesia.

Karney, B. R., \& Bradbury, T. N. (1995). The longitudinal course of marital quality and stability: A review of theory, methods, and research. Psychological bulletin, 118(1), 3.

Kerr, S. L., O'Donovan, A., \& Pepping, C. A. (2015). Can gratitude and kindness interventions enhance well-being in a clinical sample?. Journal of Happiness Studies, 16(1), 17-36.

Layous, K., Chancellor, J., \& Lyubomirsky, S. (2014). Positive activities as protective factors against mental health conditions. Journal of Abnormal Psychology, 123(1), 3-12. https://doi.org/10.1037/a0034709

Lyubomirsky, S., \& Layous, K. (2013). How do simple positive activities increase wellbeing?. Current Directions in Psychological Science, 22(1), 57-62.

Mohsin, F. Z. (2014). Marital satisfaction and job satisfaction: a study of dual and single-earner couples. Pakistan Business Review.

O’Connell, B. H., O’Shea, D., \& Gallagher, S. (2016). Enhancing social relationships through positive psychology activities: a randomised controlled trial. Journal of Positive Psychology, 11(2), 149-162. https://doi.org/10.1080/17439760.2015.1037860

Olson, D. H., \& DeFrain, J. (2006). Marriages and families: intimacy, diversity and strengths ( $5^{\text {th }}$ Ed.). New York: McGraw Hill.

Otake, K., Shimai, S., Tanaka-Matsumi, J., Otsui, K., \& Fredrickson, B. L. (2006). Happy people become happier through kindness: A counting kindnesses intervention. Journal of Happiness Studies, 7(3), 361-375. https://doi.org/10.1007/s10902-005-3650-z

Papalia, D. E., Olds, S. W., \& Feldman, R. D. (2009). Human Development (1 ${ }^{\text {th }}$ Ed.) New York: McGraw Hill.

Ross, C. E., Mirowsky, J., \& Goldsteen, K. (1990). The impact of the family on health: The decade in review. Journal of Marriage and Family, 52(4), 1059.

Sari, M. N., Yusri, Y., \& Sukmawati, I. (2015). Faktor Penyebab Perceraian dan Implikasinya dalam Pelayanan Bimbingan dan Konseling. Jurnal Konseling dan Pendidikan, 3(1), 1621. 
Seligman, M. E. P., Steen, T. A., Park, N., \& Peterson, C. (2005). Positive psychology progress: empirical validation of interventions. The American Psychologist, 60(5), 410-421. https://doi.org/10.1037/0003-066X.60.5.410

Sheldon, K. M., \& Lyubomirsky, S. (2006). How to increase and sustain positive emotion: The effects of expressing gratitude and visualizing best possible selves. Journal of Positive Psychology, 1(2), 73-82. https://doi.org/10.1080/17439760500510676

Sin, N. L., \& Lyubomirsky, S. (2009). Enhancing well-being and alleviating depressive symptoms with positive psychology interventions: A practice-friendly meta-analysis. Journal of clinical psychology, 65(5), 467-487.

Stone, E., \& Shackelford, T. (2007). In R. F. Baumeister \& K. D. Vohs (Eds.), Encyclopedia of social psychology. Thousand Oaks, CA: Sage.

Williams, B. K., Sawyer, S. C., \& Wahlstrom, C. M. (2006). Marriages, families, \& intimate relationships. New York, NY: Pearson. 